\title{
Menelisik Pengelolaan Human Capital di Dunia Bisnis dalam Era New Normal: Studi Kasus pada Generasi Milenial di Bali
}

\author{
Desak Made Diah Prama Yanti \\ I Gede Sanica \\ Manajemen, Universitas Pendidikan Nasional, Indonesia \\ Korespondensi penulis: dpramayanti@gmail.com
}

\begin{abstract}
This study analyzes strategies that can be used in managing human capital in the millennial generation in the current new normal era and to find out the supporting and inhibiting factors in managing human capital during the covid-19 pandemic. The research method used is a qualitative research method with a case study model approach. The research location is in Denpasar City, Bali Province. The selection of informants used the purposive sampling technique by determining four companies from various fields as informants, namely Garment, Vila, Cargo, and University. Data in this study analyzes the results of observations, interviews, and documentation obtained. Data analysis uses source triangulation through four stages: data collection, data reduction, data presentation, and drawing conclusions or verification. The study results stated that the human capital management strategy for millennial employees in the new normal era had been affected on two sides. First, from the company side were the COVID-19 pandemic had an impact on decreasing company income and reducing operational activities. For this reason, changes are made, such as dividing work schedules and hours. Employee work, distribution of the rolling system, some employees work from home (WFH), and maximize employee skills into multitasking. Meanwhile, from the employee's perspective, it impacts the income of the employee, where employees receive a much-reduced salary or income, even if they are dismissed at any time to reduce operational costs.
\end{abstract}

Keywords: Covid-19; Human capital; Management strategy; Millennial generation; New normal.

\begin{abstract}
Abstrak. Penelitian ini bertujuan untuk menganalisis strategi yang digunakan untuk mengelola human capital di dunia bisnis pada era new normal saat ini berdasarkan faktor-faktor pendukung dan penghambat pada kalangan generasi milenial. Metode penelitian yang digunakan adalah metode penelitian kualitatif dengan pendekatan model studi kasus. Lokasi penelitian berada di Kota Denpasar, Provinsi Bali. Pemilihan informan menggunakan teknik purposive sampling dengan menetapkan empat orang informan yang berasal dari perusahaan berbagai bidang, yaitu perusahaan garmen (industri pakaian), vila (tempat penginapan), kargo (pengiriman barang), dan sekolah tinggi (pendidikan tinggi). Teknik pengambilan data dalam penelitian ini dilakukan dengan wa-
\end{abstract}


wancara, observasi, dan dokumentasi relevan yang diperoleh dari penelitian lapangan. Analisis data menggunakan triangulasi sumber melalui empat tahapan, yaitu pengumpulan data, reduksi data, penyajian data, dan penarikan kesimpulan atau verifikasi. Hasil penelitian menunjukkan bahwa strategi pengelolaan human capital pada karyawan generasi milenial di dunia bisnis dalam era new normal telah berdampak pada dua sisi. Dampak pertama di sisi perusahan, pandemi covid-19 berdampak pada menurunnya penghasilan perusahaan dan berkurangnya aktivitas operasional usaha, sehingga perusahaan melakukan perubahan strategi, seperti membagi jadwal kerja dan jam kerja karyawan, membagi sistem rolling, sebagian karyawan diminta bekerja dari rumah (Work from Home atau WFH), dan memaksimalkan skill karyawan menjadi multitasking. Dampak kedua di sisi karyawan, kondisi saat ini memberikan dampak pada segi pemasukan karyawan, yaitu karyawan menerima gaji atau pendapatan yang jauh berkurang dari sebelumnya. Bahkan, karyawan harus bersiap menerima keputusan drastis perusahaan, jika sewaktu-waktu mereka terpaksa diberhentikan demi menekan biaya operasional perusahaan.

Kata kunci: Covid-19; Generasi milenial; Kenormalan baru; Modal manusia; Strategi manajemen.

Article Info:

Received: May 14, $2021 \quad$ Accepted: September 15, $2021 \quad$ Available online: September 29, 2021 DOI: http://dx.doi.org/10.30588/jmp.v11i1.840

\section{LATAR BELAKANG}

Human capital merupakan salah satu sumber keunggulan kompetitif dan elemen kunci penting untuk meraih kesuksesan perusahaan dalam menghadapi persaingan bisnis. Oleh karena itu, pengelolaan human capital bagi organisasi bisnis adalah hal yang krusial. Tujuan organisasi bisnis sulit terwujud tanpa peran aktif karyawannya, meskipun alat-alat penunjang yang dimiliki perusahaan sudah cukup canggih. Alat-alat canggih yang dimiliki perusahaan tidak akan berfungsi dengan baik bagi perusahaan, apabila peran aktif karyawan tidak diikutsertakan (Hasibuan, 2016). Mengatur karyawan merupakan tugas yang tidak mudah. Kesulitan tersebut semakin tinggi ketika dihadapkan pada pengelolaan karyawan generasi milenial yang kini semakin banyak mengisi bagian-bagian penting di organisasi-organisasi bisnis yang ada, karena mereka mempunyai pikiran, perasaan, keinginan, dan latar belakang yang berbeda-beda dan dibawa ke dalam organisasi. Karyawan tidak dapat diatur begitu saja sesuai dengan apa yang diinginkan perusahaan. Salah satu persoalan penting dan menjadi tantangan dalam perusahaan saat ini adalah pengelolaan human capital.

Data statistik gender tematik mengenai profil generasi milenial Indonesia menunjukkan Tingkat Partisipasi Angkatan Kerja (TPAK) yang menggambarkan persentase angkatan kerja terhadap penduduk usia kerja (Kementerian Pemberdayaan Perempuan dan Perlindungan Anak, 2018). Gambar 1 menunjukkan data Tingkat Partisipasi Angkatan Kerja (TPAK), baik berdasarkan generasi maupun daerah tempat tinggalnya. Secara keseluruhan, TPAK dari generasi milenial (Generasi Y) pada tahun 2017 mencapai duapertiga dari populasi angkatan kerja generasi tersebut, yaitu $67,24 \%$. Dengan kata lain, masih ada sekitar sepertiga atau 30\% dari generasi milenial yang tergolong 
bukan angkatan kerja. Hal tersebut dikarenakan di antara mereka yang termasuk generasi milenial masih berada pada fase sekolah, yaitu pada rentang usia 16-24 tahun. Di sisi lain, sekitar delapan dari sepuluh orang dari Generasi X termasuk angkatan kerja atau tercatat sebesar 78,99\%. Tingkat partisipasi tertinggi adalah TPAK pada Generasi $\mathrm{X}$ jika dibandingkan dengan Generasi milenial (Y) dan Generasi Baby Boom+Veteran. Hal tersebut dapat terjadi, karena rentang usia Generasi $\mathrm{X}$ berada pada kisaran 38-57 tahun, sehingga kelompok umur tersebut telah melampaui usia sekolah dan memiliki tingkat produktivitas yang tinggi. Sementara itu, 52,40\% atau hanya sekitar setengah dari Generasi Baby Boom+Veteran yang masih berpartisipasi sebagai angkatan kerja produktif. Namun, tingkat partisipasi angkatan kerja Generasi Baby Boom+Veteran tercatat paling kecil pada periode tersebut, karena tingkat produktivitas mereka telah mengalami penurunan yang signifikan.

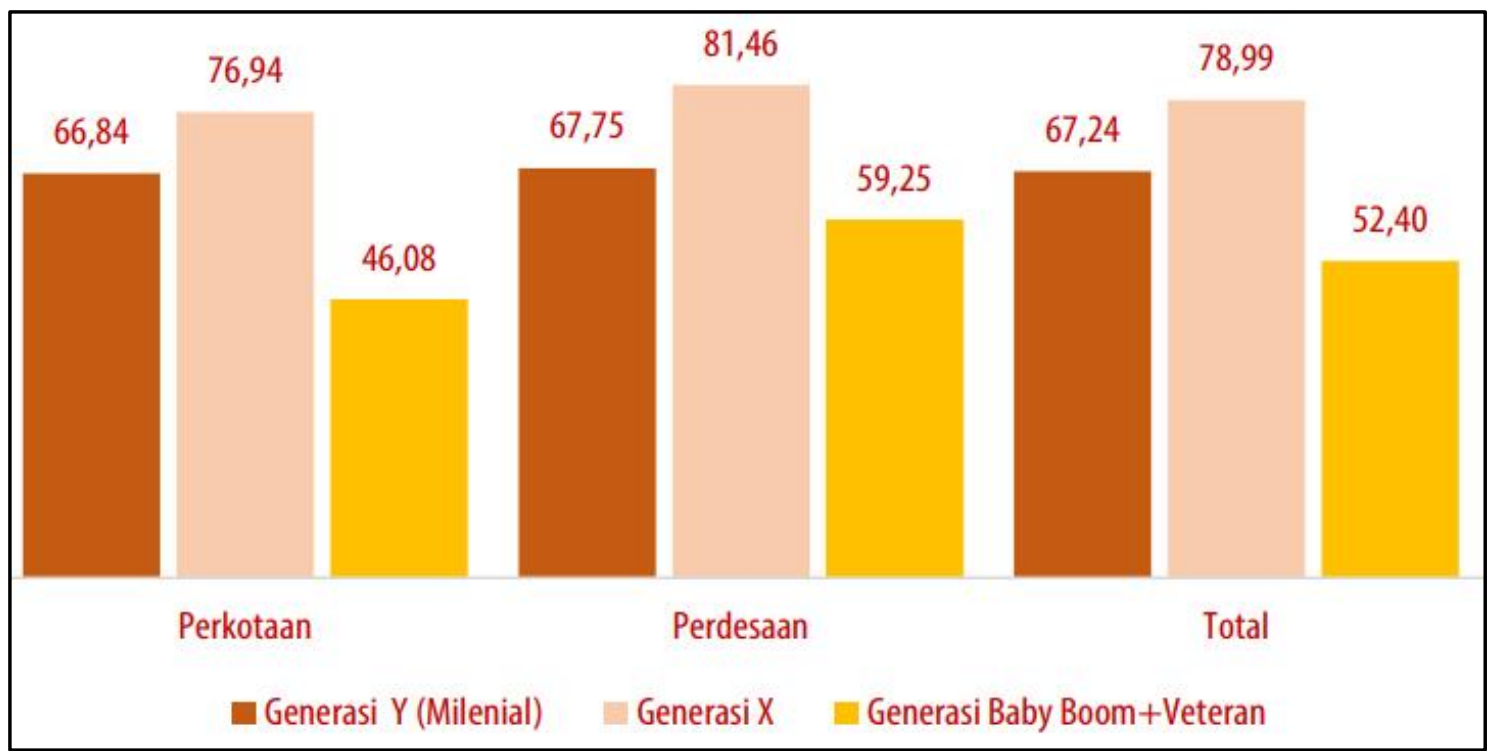

Sumber: Kementerian Pemberdayaan Perempuan dan Perlindungan Anak (2018).

\section{Gambar 1. Tingkat Partisipasi Angkatan Kerja (TPAK) Menurut Generasi dan Daerah Tempat Tinggal Tahun 2017 (dalam \%)}

Menurut Abbas (2019), beberapa isu strategis yang menarik dalam pengelolaan human capital adalah ketersediaan sumber daya manusia (SDM) yang energik, kreatif, inovatif, dan profesional. Tantangan bagi Human Resource Department (HRD) lainnya adalah menghadapi generasi milenial yang cenderung tidak nyaman dalam menjalani suatu pekerjaan yang monoton, sehingga tingkat turn over mereka cenderung tinggi. Hal tersebut dapat terjadi, karena sebagian dari generasi milenial masih dalam proses mencari pekerjaan yang dirasakan tepat sesuai keinginannya, dan mereka merasa cepat puas dengan masa kerja yang lebih pendek dibandingkan dengan masa kerja generasi sebelumnya (Faiza \& Firda, 2018). Peningkatan gaji atau pemberian bonus kadang bukan menjadi solusi melainkan faktor lingkungan dan suasana kerja interaktif yang diciptakan dan dimaksimalkan oleh manajemen human capital untuk memberikan rasa nyaman bekerja (LonivHR, 2017). Perubahan yang terlihat di permukaan menunjukkan bahwa generasi milenial tidak terlalu suka cara bekerja yang bersifat tradisional, mulai 
dari penetapan jam kerja yang monoton sampai dengan aturan cara berpakaian dalam bekerja di kantor. Hal penting yang perlu dibenahi oleh HRD adalah upaya menata dan mengatur ulang agar kebijakan dan strategi perusahaan mendukung kinerja generasi milenial.

Semakin pesatnya perkembangan teknologi informasi di dunia industry dapat memberikan dampak terhadap kebutuhan perusahaan untuk mengelola human capital secara lebih kompeten dan memiliki motivasi untuk terus berkembang atau sustainable growth (Fareed, Noor, Isa, \& Salleh, 2016). Saat ini, dunia bisnis sedang berada dalam kemajuan pesat dengan dukungan perkembangan teknologi informasi yang berpengaruh terhadap tatanan industri yang dikenal dengan era industri 4.0 (Satya, 2018). Di era industri 4.0 ini, gelombang pekerja milenial identik dengan perkembangan teknologi. Tidak mudah memastikan agar kaum milenial ini dapat bekerja dengan baik di perusahaan (Ong \& Mahazan, 2020). Keberadaan internet, wifi, laptop dan smartphone memungkinkan mereka saling terhubung dan memiliki perspektif global. Penting untuk memahami generasi milenial di tempat kerja adalah memahami nilai dan sikap kerja mereka. Berfokus pada etos kerja, generasi milenial kurang menghargai pekerjaan untuk kepentingannya sendiri (Smola \& Sutton, 2002; Twenge, Campbell, Hoffman, \& Lance, 2010) dan mereka kurang menunjukkan minat untuk bekerja keras, bekerja lembur, dan bangga dengan pekerjaan mereka sendiri daripada sebelumnya, mereka melakukannya saat masih muda (Ciriello, Dempsey, Maikala, \& O’Brien, 2008).

Generasi milenial cenderung tertarik pada perusahaan yang menggunakan teknologi informasi (Kumparan, 2017). Mereka tidak mau terikat pada tempat kerja tertentu dan selalu terhubung dengan internet. Aplikasi HRD modern mendukung para pekerja generasi milenial dengan hanya satu tombol sentuh. Training dapat dilakukan melalui video dan modul-modul e-learning. Namun, perubahan gaya bekerja yang terjadi tersebut bukan tanpa konsekuensi. Karakter generasi milenial yang berbeda dengan generasi sebelumnya dalam memandang makna karir pekerjaan juga menimbulkan konsekuensikonsekuensi baru bagi perusahaan untuk mengelola SDM yang sesuai dan adaptif dengan kelompok milenial sebagai angkatan kerja terbesar kedua setelah generasi $\mathrm{X}$ (Kementerian Pemberdayaan Perempuan dan Perlindungan Anak, 2018). Keberlanjutan karyawan generasi milenial dalam bekerja ini perlu mendapatkan perhatian oleh perusahaan, sehingga potensi-potensi untuk mempertahankan karyawan milenial perlu dilakukan manajemen perusahaan.

Penelitian oleh pusat studi Center of Human Capital Development (CHCD) pada tahun 2017 menyatakan bahwa beberapa penyebab bertahannya karyawan milenial di Indonesia di antaranya adalah income atau salary, kepemimpinan yang baik, keseimbangan antara pekerjaan dengan kehidupan dan manajemen yang solid, serta jenis dan karakter pekerjaan yang dirasakan sesuai dengan keinginan mereka (Febrianindya, 2018). Perubahan peraturan perusahaan dalam mengatur kegiatan bekerja karyawan dipengaruhi oleh perubahan yang terjadi di dunia bisnis. Perubahan merupakan refleksi dari ketegasan di dalam perusahaan yang bertujuan untuk memberikan ketertiban, kenyamanan, dan arahan di dalam melakukan proses pekerjaan (Tampubolon, 2020). Contohnya, peraturan pemerintah mengatur jam kerja selama delapan jam dalam sehari. Namun, adanya era disrupsi saat ini lambat laun jam kerja digantikan dengan jam produktivitas, seperti yang terjadi pada usaha berbasis online (Kasali, 2017). Misalnya, marketplace pada online shopping dan driver kendaraan online yang tidak mempunyai batasan jam dalam bekerja. Namun, produktivitas kerja karyawan dapat mencerminkan 
daya pikir, inovatif, kreatif, dan kemampuan mengembangkan softskill. Semakin tinggi kemampuan tersebut, maka semakin tinggi pula produktivitasnya. Untuk merumuskan strategi mengembangkan SDM, perusahaan perlu memperhatikan faktor perkembangan teknologi sebagai tolak ukur utama dalam perubahan pengelolaan human capital dalam menjawab tantangan masa depan (Fudin, 2019).

Pandemi global Covid-19 di Indonesia telah berlangsung lebih dari setahun sejak bulan Maret tahun 2020. Pemerintah masih berupaya melakukan langkah-langkah mitigatif dan penanganan dampak pandemi seoptimal mungkin agar Covid-19 tidak semakin menyebar dan membawa korban jiwa lebih banyak lagi. Beragam strategi dan kebijakan pun ditempuh untuk menekan penyebaran virus ini mulai dari physical distancing sampai dengan Pembatasan Sosial Berskala Besar (PSBB) yang dilakukan di berbagai daerah. Namun, tidak ada pihak mana pun yang mampu memperkirakan kapan pandemi Covid-19 ini akan berakhir. Pandemi Covid-19 terbukti membawa pengaruh signifikan terhadap berbagai sektor, khususnya perekonomian negara dan masyarakat. Banyak perusahaan terkena dampak pandemi Covid-19 ini, sehingga sebagian dari mereka terpaksa harus mengurangi jumlah karyawan, baik dengan cara merumahkannya sementara hingga melakukan pemutusan hubungan kerja (PHK). Pada akhirnya, kondisi tersebut membawa pemerintah dan masyarakat Indonesia pada pemahaman munculnya era new normal atau tatanan kehidupan normal yang baru sebagai respon realistis terhadap eksistensi Covid-19 (Bramasta, 2020). Era kenormalan baru diartikan pula sebagai perubahan perilaku manusia untuk melakukan aktivitas dengan cara berbeda dari kondisi sebelum terjadinya pandemi, sehingga kondisi yang tidak tidak normal akan menjadi normal kembali dengan cara dan pendekatan yang baru (Indrawati, 2020).

Berdasarkan observasi awal yang dilakukan sebelum penelitian ini, ada beberapa hal yang muncul sebagai tantangan bagi HRD untuk mengelola generasi milenial dalam bekerja. Pada awalnya, mereka bekerja dengan kecenderungan berpikir secara instan, berkomunikasi dengan kurang baik, dan tidak disiplin terhadap waktu. Di satu sisi, generasi milenial ini cukup trampil dalam penguasaan teknologi informasi, sehingga mereka perlu bimbingan dan acuan untuk mengimbangi aktivitas dunia kerja menuju sikap yang profesional. Pada umumnya, generasi milenial cepat menangkap dalam mempelajari sesuatu yang baru, tetapi mereka juga kadang menyepelekan pekerjaannya. Mereka mampu melaju pesat dengan kemampuan kreatif dan inovatif, tetapi mereka memerlukan bimbingan dan arahan yang tepat. Tanpa panduan yang tepat, mereka akan menjadi karyawan yang lebih sulit untuk dikendalikan. Berdasarkan uraian tersebut, penelitian ini bertujuan untuk menganalisis strategi yang digunakan untuk mengelola human capital di dunia bisnis pada era new normal saat ini berdasarkan faktor-faktor pendukung dan penghambat pada kalangan generasi milenial..

\section{KAJIAN TEORITIS}

\section{Human Capital}

Jika dilihat dari struktur bahasanya, human capital terdiri atas dua kata, yaitu manusia dan modal atau kapital. Kapital diartikan sebagai salah satu faktor produksi yang dapat digunakan memproduksi barang atau jasa tanpa menggunakannya selama proses produksi (Nurkholis, 2018). Arti kata kapital tersebut menunjukkan bahwa manusia dalam ruang lingkup human capital dikategorikan sebagai bentuk modal yang sama kedudukannya dengan mesin dan teknologi. Peran atau tanggung jawab manusia 
dibebankan pada setiap aktifitas ekonomi, seperti memproduksi, mengkonsumsi, dan melakukan transaksi. Sejalan dengan berkembangnya konsep ini, teori human capital dapat diartikan menjadi tiga konsep. Pertama, konsep human capital sebagai individual. Konsep ini mendeklarasikan bahwa modal manusia adalah suatu kemampuan yang berasal dari diri manusia, seperti pengetahuan dan ketrampilan. Rastogi (2002) dalam penelitiannya menyatakan bahwa seluruh pengetahuan, perilaku, kesehatan, sifat, dan kompetensi merupakan human capital.

Menurut Salehudin (2010), konsep human capital didasarkan pada premis utama bahwa human capital menempatkan manusia bukan sekedar sumber daya, tetapi manusia juga merupakan modal (capital) yang menghasilkan pengembalian (return) dan setiap pengeluaran yang dilakukan dalam rangka mengembangkan kualitas maupun kuantitas modal tersebut merupakan kegiatan investasi. Modal manusia (human capital) menjadi faktor kunci kesuksesan perusahaan, karena manusia menyediakan kemampuan untuk bersaing bagi perusahaan di masa yang akan datang. Modal manusia dipersepsikan sebagai darah kehidupan bagi modal intelektual (Firnaliyanti, Mintarti, \& Asmapane, 2020). Manusia juga dapat dipandang sebagai detonator dari seluruh nilai yang lahir di dalam potensi inovasi perusahaan. Manusia menjadi faktor penentu di balik modal intelektual dan inovasi perusahaan, sumber inovasi, dan renewal (Sangkala, 2006). Di dalam diri manusia terkandung kompetensi, ketrampilan, dan pengetahuan. Manusia juga dikaitkan dengan nilai pengetahuan pribadi dan komitmen penting atas tujuan organisasi. Amstrong dan Taylor (2014) mengatakan bahwa signifikansi human capital adalah teori yang menganggap orang sebagai aset dan investasi organisasi pada manusia akan menghasilkan keuntungan yang berharga.

Hasil penelitian sebelumnya oleh Priyana (2016), mengkaji dan mengetahui faktor-faktor yang menghambat atau menjadi tantangan dalam pemberdayaan sumber daya manusia di perusahaan dan perbaikan implementasi pemberdayaan sumber daya manusia, sehingga mendukung upaya optimalisasi potensi human capital di perusahaan. Selain itu, hasil penelitian ini tentang upaya untuk mengoptimalkan potensi human capital yang dilakukan oleh Kharisma, Prasilowati, \& Ayuningtyas (2019) menunjukkan bahwa aspek pemberdayaan yang diimplementasikan dengan baik oleh perusahaan adalah aspek motivasi, pengambilan keputusan, dan aspek kepercayaan yang dimiliki oleh karyawan, sedangkan aspek yang sangat lemah dan perlu mendapatkan prioritas khusus adalah aspek stagnan mindset. Penelitian tersebut juga menemukan bahwa perusahaan yang dianalisis memiliki potensi dalam aspek pengetahuan dan kemampuan yang besar dalam pengelolaan human capital, sedangkan aspek keahlian dan ketrampilan masih diperlukan upaya-upaya untuk memaksimalkannya.

\section{Pengelolaan Human Capital}

Menurut Musthofa (2020), kesuksesan organisasi sangat ditentukan oleh kumpulan sumber daya manusia yang memiliki bakat tinggi. Untuk itu, sumber daya manusia yang memiliki bakat dan talenta akan menjadi keunggulan kompetitif utama dan aset penting bagi perusahaan dalam menghadapi persaingan bisnis di era global yang menuntut daya adaptasi tepat dalam menghadapi berbagai perubahan yang semakin turbulen dan kompleks. Pengelolaan human capital didasarkan pada teori modern untuk mengelola realitas baru dengan cara baru dalam berpikir dan bersikap terhadap hal-hal yang kontroversial, sehingga pengelolaan aset manusia sangat dibutuhkan pada situasi lingkungan organisasi, masyarakat, dan individu yang dinamis dan selalu berubah. 
Burud dan Tumolo (2004) memiliki konsep yang menyatakan bahwa pengelolaan human capital dan penetapan strategi perusahaan berguna untuk hasil dan proses transformasi yang dilakukan, sehingga pengelolaan tersebut setidaknya dilandasi oleh faktorfaktor berikut ini:

1. Kekuatan dalam kerja sebagai kenyataan baru yang diyakini bahwa tujuan organisasi bukan hanya berorientasi untuk mencari keuntungan semata melainkan juga memiliki komitmen untuk saling terbuka dan transparan dalam suatu hubungan lingkungan kerja, sehingga kekuatan tersebut dapat memicu adanya perasaan tanggung jawab terhadap tugas dan pekerjaan.

2. Manusia menjadi faktor dalam menentukan pencapaian tujuan organisasi dengan menerapkan intellectual capital (seperti bakat, pengetahuan, dan keahlian) dan relationship capital (seperti layanan terhadap pelanggan dan stokeholders).

3. Manusia merupakan unsur sangat penting untuk mendapatkan keunggulan dalam berkompetisi melalui inovasi dan kreativitas, serta pengetahuan yang dimiliki, komunikasi dengan pelanggan, rekan kerja, dan ruang lingkup profesionalitas.

4. Strategi memiliki kekuatan adaptasi untuk menelusuri human capital yang terletak pada cara praktis dalam beradaptasi yang mencakup: (a) orang sebagai sarana dalam strategi berinvestasi; (b) keyakinan baru adalah hasil dari pengadopsian strategi; (c) budaya organisai yang dipahami melalui strategi; (d) strategi sebagai refleksi praktik manajemen; dan (e) strategi untuk memastikan kesesuaian antara keyakinan, budaya, dan praktik.

\section{Strategi}

Menurut Yulita, Nugroho, dan Astuti (2018), manajemen strategi merupakan proses pengambilan keputusan dan tindakan yang mengarah kepada pengembangan strategi yang efektif atau membantu perusahaan mencapai tujuannya. Manajemen strategi adalah suatu proses yang dinamis karena berlangsung secara terus menerus dalam suatu perusahaan. Setiap strategi selalu memerlukan peninjauan ulang dan perubahan di masa depan. Menurut Hariadi (2003), manajemen strategi adalah proses strategi yang dirancang oleh manajemen untuk merumuskan strategi, melaksanakan, dan mengevaluasinya. Kegiatan tersebut untuk menentukan keberhasilan perusahaan dalam jangka panjang dalam mencapai tujuannya. Pengertian strategi mengarah pada penjelasan mengenai implementasi strategi. Menurut Yunus (2016), strategi merupakan cara dari rencana kegiatan yang mengklasifikasikan alokasi sumber daya dan aktifitas lain untuk merespon suatu situasi lingkungan dan membantu organisasi untuk mencapai targetnya. Secara sederhana, strategi dipahami sebagai cara untuk melakukan kegiatan yang berbeda atau dengan cara berbeda dari pesaingnya. Yunus (2016) memaknai manajemen strategi sebagai berikut:

1. Manajemen memilih strategi untuk dilaksanakan dan dievaluasi secara efektif dan efisien.

2. Manajemen meninjau, mengevaluasi, dan mengkaji ulang situasi dalam kinerja, serta melakukan berbagai perubahan untuk menyesuaikan dan melakukan perbaikan, apabila suatu hal yang menyimpang di dalam pelaksanaan implementasi strategi ditemukan.

3. Manajemen selalu melakukan pembaruan mengikuti berbagai perkembangan lingkungan di luar perusahaan untuk merumuskan strategi perusahaan. 
4. Manajemen selalu mempertimbangkan dan meninjau kembali analisis SWOT yaitu Strengths (kekuatan), Weaknesses (kelemahan), Opportunities (peluang), dan Threats (ancaman) yang ada.

5. Manajemen selalu memperbarui produk atau jasa dengan inovasi-inovasi sesuai selera konsumennya.

Aktivitas untuk memformulasikan strategi sesungguhnya dapat memperbesar kemampuan perusahaan dalam menemukan solusi dari setiap permasalahan yang dihadapinya (Yunus, 2016). Proses manajemen strategi dapat membuahkan keputusan yang tepat dan terbaik. Hal itu dikarenakan adanya keterlibatan dan interaksi kelompok yang dapat menghasilkan strategi yang lebih tepat.

\section{Manajemen Strategi}

Manajemen strategis diartikan sebagai bagian dari rencana yang ditata dan dikelola dengan mempertimbangkan kepentingan berbagai pihak dengan tujuan agar pengaruh rencana tersebut memberikan implikasi positif bagi organisasi secara jangka panjang (Fahmi, 2013). Penerapan manajemen strategis diharapkan mampu memberikan hasil pencapaian terbaik dan keberlanjutan organisasi. Profit yang stabil dipengaruhi oleh stabilitas penjualan yang secara terus menerus mengalami pertumbuhan positif. Manajemen strategi merupakan seni dan ilmu dalam menyusun, menerapkan, dan mengevaluasi keputusan manajemen yang akan dilakukan demi pencapaian tujuan organisasi (David \& David, 2017).

Secara umum, strategi berbicara mengenai isu-isu yang menjangkau lebih dari satu periode anggaran atau bersifat jangka panjang. Manajemen strategik membahas persoalan organisasi yang berdimensi masa depan, bukan masa kini atau masa lalu (Triangga, Mubyl, \& Abdullah, 2020). Manajemen strategi maupun perencanaan strategi, keduanya membutuhkan sebuah rencana yang baik agar memiliki kemampuan daya saing, mampu bertahan, dan memiliki peluang untuk sukses. Dalam kegiatan untuk mencapai sasaran-sasaran yang diinginkan oleh perusahaan, manajemen strategi memiliki fungsi untuk merencanakan langkah-langkah yang akan diambil. Selanjutnya, manajemen memutuskan untuk menerapkannya, sehingga apabila proses pelaksaaannya terjadi kekurangan, maka manajemen dapat segera memeriksa atau mengevaluasinya untuk diatasi. Secara keseluruhan, manajemen strategi merupakan proses perusahaan untuk membuat rencana strategis, membuat keputusan strategis, dan meninjau ulang strategi yang sudah berjalan agar dapat diketahui kekuatan dan kelemahannya untuk penyempurnaan.

\section{Perumusan Strategi}

Perumusan strategi adalah proses menyusun langkah-langkah untuk masa yang akan datang bagi perusahaan bertujuan untuk membangun visi dan misi perusahaan, menetapkan tujuan strategis, dan merancang strategi untuk mencapai tujuan tersebut dalam rangka menciptakan kepercayaan dan kepuasan konsumen (Taufiqurokhman, 2016). Strategi yang telah disusun dan ditetapkan harus sejalan dengan tujuan perusahaan, sehingga secara bertahap dapat meningkatkan posisi perusahaan ke arah yang lebih baik. Ada beberapa tingkatan dalam strategi untuk perusahaan besar. Menurut Wheelen dan Hunger (2010), tiga tingkatan strategi manajemen yang berkembang sesuai dengan perkembangan perusahaan adalah: 


\section{Strategi Korporasi}

Strategi tingkat korporasi dicetuskan dan dirancang oleh manajemen puncak dan dibuat sedemikian rupa untuk mendukung tercapainya tujuan organisasi. Merumuskan strategi korporasi di dalam organisasi berskala besar akan lebih rumit dikarenakan banyak strategi tingkat bisnis yang jauh berbeda dan memerlukan koordinasi untuk mencapai tujuan perusahaan secara keseluruhan.

2. Strategi Bisnis

Strategi tingkat bisnis direncanakan oleh masing-masing departemen atau unit bisnis pada sebuah organisasi. Pada umumnya, strategi bisnis diformulasikan oleh manajer unit bisnis melalui negosisasi dan kesepakatan dengan manajer korporasi dan fokus pada cara bersaing dalam dunia bisnis. Manajer korporasi perlu memberikan dukungan dan persetujuan pada rencana strategi bisnis.

3. Strategi Fungsional

Strategi tingkat fungsional adalah penyusunan strategi berdasarkan fungsinya. Upaya yang dilakukan adalah memaksimalkan sumber daya dengan spesialisasinya untuk meningkatkan produktivitas. Strategi fungsional fokus pada pengembangan dan pemeliharaan kompetensi atau keahlian khusus untuk menghasilkan produk unggul dan memiliki daya saing kuat pada unit bisnisnya.

\section{Generasi Milenial (Generasi Y)}

Ali dan Purwandi (2017) menyebutkan bahwa generasi milenial atau Generasi Y adalah orang yang lahir di antara tahun 1981 hingga tahun 2000 (era milenium). Dari sisi pemikiran dan pandangan, generasi milenial memiliki banyak perbedaan jika dibandingkan dengan generasi sebelumnya. Generasi Y lahir dan besar dalam situasi ekonomi, sosial, dan politik yang bergejolak dan melanda Indonesia yang diawali dengan krisis moneter pada tahun 1998. Generasi milenial dapat dikatakan sebagai generasi yang erat kaitannya dengan gerakan reformasi. Generasi milenial bertumbuh menjadi individu-individu yang memiliki pemikiran terbuka, mengutamakan kebebasan berekspresi, kritis, dan berani melakukan sesuatu yang baru. Hingga saat ini, situasi dan kondisi pemerintahan yang terbuka dan kondusif mencerminkan apa yang yang telah dirintis oleh generasi milenial. Dari sisi pekerjaan, Gallup (2016) menyebutkan bahwa generasi milenial memiliki kepribadian dan karakter yang jauh berbeda dengan generasi-generasi sebelumnya, di antaranya adalah:

1. Gaji bukan tujuan utama mereka dalam bekerja melainkan juga untuk mencari jati diri dan tujuan utama yang sudah dicita-citakan sebelumnya.

2. Kurangnya orientasi mengenai kepuasan kerja pada generasi milenial, karena yang lebih diinginkan adalah kemungkinan berkembangnya diri mereka dalam pekerjaan tersebut (mempelajari sesuatu yang baru, keahlian baru, memiliki pandangan dari sudut yang berbeda-beda, mengenal lebih banyak karakter orang, dan memanfaatkan kesempatan untuk berkembang).

3. Generasi milenial tidak suka dengan atasan yang otoriter dan suka memerintah, tetapi mereka lebih suka dengan pemimpin yang mampu memberikan contoh, low profile, serta mengarahkan dan mengayomi karyawannya.

4. Generasi milenial tidak ingin dinilai dalam periode tahunan terhadap kinerjanya, tetapi mereka menginginkan penilaian atas apa yang sedang berlangsung.

5. Generasi milenial lebih berorientasi pada pengembangan diri dibandingkan dengan memperbaiki kekurangannya. 
6. Generasi milenial menganggap pekerjaan sebagai salah satu bagian dalam perjalanan hidupnya.

\section{Era New Normal}

Terjadinya pandemi global Covid-19 sejak tahun 2020 telah mengubah banyak tatanan kehidupan masyarakat. Di Covid-19 telah menciptakan era baru yang juga dikenal sebagai era kenormalan baru (new normal). Pada zaman kenormalan baru, segala aktifitas masyarakat terutama kegiatan ekonomi dan bisnis dilakukan dengan cara-cara baru dengan menerapkan protokol kesehatan, mengikuti peraturan yang telah diterapkan pemerintah, dan melakukan kegiatan-kegiatan maupun prosedur preventif yang terkait dengan pencegahan penularan Covid-19. Hal itu dilakukan agar setiap aktivitas yang dilakukan, baik itu di sektor pemerintahan, swasta, maupun kegiatan masyarakat pada umumnya telah dinyatakan aman berdampingan dengan Covid-19. Mau tidak mau, saat ini masyarakat harus selalu siap dengan perubahan yang terus menerus mengarah pada tatanan kehidupan di era baru. Pada dasarnya, Indonesia telah banyak melakukan perubahan-perubahan yang dinilai dapat mengurangi dampak pandemi Covid-19 yang telah memakan banyak korban jiwa.

Penerapan tatanan kehidupan baru atau new normal di Indonesia telah diatur dalam Keputusan Menteri Kesehatan nomor HK.01.07/MENKES/328/2020 tentang Panduan Pencegahan dan Pengendalian Covid-19 di Tempat Kerja Perkantoran dan Industri sebagai upaya mendukung berlangsungnya perekonomian yang sehat di tengah situasi pandemi yang melanda berbagai negara termasuk Indonesia saat ini (Rosidi, 2020). Peraturan Pemerintah nomor 21 tahun 2020 tentang Pembatasan Sosial Berskala Besar (PSBB) dalam rangka percepatan penanganan Covid-19 telah berdampak terhadap aktivitas perekonomian khususnya pada sektor pekerja yang menerpakan kerja dari rumah atau Work from Home (WFH) (Kementerian Kesehatan Republik Indonesia, 2020). Namun, adanya pembatasan kegiatan tersebut telah membuat para pelaku usaha merasa tidak optimal memutar roda perekonomiannya. Hal ini menyebabkan banyak pengusaha lebih memilih untuk menutup usahanya dan meliburkan atau memberhentikan karyawannya. Saat ini, pemerintah terus berupaya untuk merangsang perputaran roda perekonomian dengan memberikan beberapa kebijakan insentif, seperti restrukturisasi kredit, relaksasi pajak, menghapus PPNBM, dan berusaha open border dengan negara lain (Kementerian Keuangan Republik Indonesia, 2021; Otoritas Jasa Keuangan, 2020).

\section{METODE PENELITIAN}

Penelitian ini berlokasi di wilayah Kabupaten Badung, Provinsi Bali, karena Kabupaten Badung merupakan kabupaten yang paling terpuruk akibat dampak pandemi Covid-19 dibandingkan kabupaten lainnya. Kabupaten Badung menempati posisi pertama dengan terburuk yang memiliki nilai pertumbuhan ekonomi minus 16,52 persen (Wiratmini, 2021). Fokus penelitian ini adalah unit usaha atau perusahaan yang beroperasi di Kabupaten Badung dan terdampak pandemi Covid-19. Informan dalam penelitian ini ditentukan atas dasar purposive sampling. Metode purposive sampling adalah teknik pengambilan sumber data dengan pertimbangan tertentu dengan tujuan agar sampel dianggap mampu dan memiliki data yang dibutuhkan (Sugiyono, 2018). Penentuan informan dalam penelitian ini didasarkan pada kriteria tertentu, yaitu informan merupakan pelaku utama sebagai pengelola human capital dalam perusahaan dan mereka 
bekerja di perusahaan yang mengalami dampak langsung pandemi Covid-19, serta unit usaha yang dipilih memiliki bidang usaha yang berbeda-beda, yaitu perusahaan manufaktur (garmen), akomodasi perhotelan (vila), pengiriman barang (kargo), dan pendidikan (sekolah tinggi).

Penelitian ini merupakan penelitian kualitiatf diskriptif dengan pendekatan studi kasus. Metode penelitian kualitatif adalah metode penelitian yang digunakan untuk meneliti pada kondisi obyek alamiah (Sugiyono, 2018). Metode kualitatif dapat memberikan rincian dan informasi yang sulit diungkapkan dalam metode kuantitatif, sehingga terobosan metodologis perlu dilakukan agar mampu menciptakan alternatif konsep baru dari kombinasi antara perspektif yang diteliti dan perspektif peneliti itu sendiri (Sugiyono, 2018). Pendekatan studi kasus yang diterapkan dalam penelitian ini adalah salah satu jenis pendekatan di dalam penelitian kualitatif, yaitu peneliti melakukan eksplorasi secara mendalam terhadap program, kejadian, proses, aktifitas, terhadap satu orang atau lebih (Sugiyono, 2018).

Pendekatan kualitatif diyakini mampu mengarahkan pencarian-pencarian konsep baru melalui interpretasi proses dan makna suatu fenomena yang selanjutnya dapat digunakan untuk membangun prediksi dan memberikan eksplanasi terhadap fenomena yang diteliti tersebut. Informan dalam penelitian ini adalah Manajer HRD atau pimpinan unit yang relevan dengan tugas pengelolaan human capital. Pengambilan data pada penelitian ini dilakukan dengan teknik wawancara secara mendalam dengan para informan. Selanjutnya, hasil wawancara ditranskripsikan dan digabungkan dengan hasil observasi langsung di lokasi penelitian dan hasil analisis dokumen-dokumen yang relevan pada obyek penelitian. Teknik analisis data yang digunakan pada penelitian ini adalah analisis diskriptif kualitatif. Analisis kualitatif merupakan analisis terhadap data yang berbentuk kata, kalimat, gerak tubuh, ekspresi wajah, bagan, gambar, dan foto (Sugiyono, 2018).

Analisis data dilakukan dengan menggunakan teknik triangulasi sumber melalui empat tahapan (Miles \& Huberman, 1994), yaitu data collection (pengumpulan data) yaitu mengumpulkan data yang didapatkan dengan wawancara mendalam kepada informan terpilih, observasi di lapangan dengan merekam apa yang dilihat dan didengar, serta mengumpulkan data sekunder berupa dokumen maupun referensi yang terkait dengan penelitian ini. Selanjutnya, data reduction (reduksi data) yaitu peneliti melakukan pemilihan terhadap hal-hal pokok dalam penelitian, memfokuskan hal penting, dan menyusun tema dan pola penelitian, sehingga memberikan gambaran yang lebih jelas. Berikutnya, data display (penyajian data) yaitu menyajikan data berbentuk uraian singkat sesuai hubungan dengan topik penelitian untuk mermudahkan dalam memahaminya. Tahap terakhir, conclusion drawing/verification yaitu menarik kesimpulan dan melakukan verifikasi atas kesimpulan tersebut agar dapat diterima kredibilitasnya. Penarikan kesimpulan dalam penelitian ini merupakan temuan baru yang belum pernah ada sebelumnya.

\section{HASIL DAN PEMBAHASAN}

\section{Diskripsi Obyek dan Subyek Penelitian}

Obyek penelitian ini terdiri atas tiga perusahaan dan satu organisasi pendidikan, yaitu PT Dianatina Ayu Garment (manufaktur garmen), PT Villa Diana Bali (akomo- 
dasi pariwisata), PT Diana Surya Ratna (kargo), dan STMIK Primakara (lembaga pendidikan tinggi). PT Dianatina Ayu Garment merupakan perusahaan yang berpusat di Bali dan telah berdiri sejak tahun 1983. Pada awalnya, perusahaan ini berlokasi di Jalan Buni Sari Kuta berupa toko kecil yang bernama CV Dianatina. Pada tahun 1986, perusahaan ini berkembang dan pindah lokasi di Jalan Raya Kuta nomor 104. Pada perkembangan terakhir, perusahaan ini berpindah ke tempat yang lebih luas karena jumlah karyawan yang semakin banyak, yaitu di Jalan Griya Anyar nomor 3XX yang mencakup showroom, gedung material, gedung produksi, dan kantor. Ruang lingkup atau bidang usaha perusahaan ini adalah manufaktur garmen, baik dalam bentuk mass-production (produksi massal) maupun custom.

PT Villa Diana Bali merupakan perusahaan yang bergerak di bidang akomodasi pariwisata. Pada awal berdirinya pada tahun 2002, Villa Diana Bali mulai membangun tiga private vila sebagai pondok wisata. Selanjutnya, usaha berkembang menjadi PT Villa Diana Bali pada tahun 2005 dengan bangunan model boutique hotel. Villa Diana Bali berlokasi di Jalan Kresna nomor 5 Legian, Kuta, Bali. Vila ini memiliki total 25 kamar dengan rincian dua kamar standard, delapan kamar deluxe, dua kamar junior suite, dan empat kamar suite, serta tiga unit private villa dengan masing masing tiga kamar di dalamnya. Lingkungan Villa Diana Bali memiliki kamar tamu yang dikelilingi kolam renang sentral dan taman tropis dengan kombinasi arsitektur Bali dan disain minimalis modern.

PT Diana Surya Ratna (DSR) Cargo adalah perusahaan pengangkutan kargo udara dan laut internasional dan domestik yang berlisensi penuh di Bali. Kantor dan gudang berlokasi strategis yang berjarak sekitar lima menit perjalanan dari Bandara Internasional Ngurah Rai. Perusahaan kargo ini beralamat di Jalan Raya Kuta nomor 168, Tuban, Kuta, Bali. Obyek penelitian kelima adalah STMIK (Sekolah Tinggi Manajemen Informatika dan Komputer) Primakara yang berada di bawah naungan Yayasan Primakara. Berdiri sejak tahun 2012, STMIK Primakara telah membawa warna tersendiri dalam dunia pendidikan tinggi di bidang teknologi informasi di Bali. STMIK Primakara menyelenggarakan pendidikan bidang teknologi informasi pada jenjang Strata 1 (S1). Pada tanggal 27 September 2013, STMIK Primakara resmi berdiri berdasarkan Surat Keputuasan Menteri Pendidikan dan Kebudayaan RI nomor 458/E/O/2013 yang berlokasi di Jalan Tukad Badung 135, Renon, Denpasar. STMIK Primakara memiliki tiga program studi, yakni Program Studi S1 Teknik Informatika, S1 Sistem Informasi, dan S1 Sistem Informasi Akuntansi.

Tabel 1. Identifikasi Informan

\begin{tabular}{|c|c|c|c|c|c|c|c|}
\hline Informan & $\begin{array}{c}\text { Nama } \\
\text { (inisial) }\end{array}$ & $\begin{array}{c}\text { Jenis } \\
\text { Kelamin }\end{array}$ & Jabatan & $\begin{array}{c}\text { Usia } \\
\text { (tahun) }\end{array}$ & Perusahaan & Pendidikan & $\begin{array}{c}\text { Masa } \\
\text { Kerja } \\
\text { (tahun) }\end{array}$ \\
\hline 1 & AS & $\mathrm{L}$ & Manajer HRD & 45 & $\begin{array}{l}\text { PT Dianatina } \\
\text { Ayu Garment }\end{array}$ & S1 & 12 \\
\hline 2 & $\mathrm{AJ}$ & $\mathrm{P}$ & $\begin{array}{l}\text { Manajer } \\
\text { Accounting dan } \\
\text { HRD }\end{array}$ & 48 & $\begin{array}{l}\text { PT Villa Diana } \\
\text { Bali }\end{array}$ & S1 & 8 \\
\hline 3 & NA & $\mathrm{L}$ & $\begin{array}{l}\text { Manajer } \\
\text { Accounting dan } \\
\text { HRD }\end{array}$ & 41 & PT DSR Cargo & $\mathrm{S} 1$ & 10 \\
\hline 4 & $\mathrm{AD}$ & $\mathrm{L}$ & $\begin{array}{l}\text { Kepala Bagian } \\
\text { HRD }\end{array}$ & 25 & $\begin{array}{l}\text { STMIK } \\
\text { Primakara }\end{array}$ & S1 & 3 \\
\hline
\end{tabular}

Keterangan: HRD = Human Resource Development.

Sumber: Hasil wawancara dalam pengumpulan data primer (2021). 
Penelitian ini melibatkan empat orang subyek penelitian sebagai informan. Keempat informan tersebut adalah manajer atau pimpinan unit kerja di bidang sumber daya manusia pada perusahaan atau organisasinya. Keempatnya terlibat secara langsung dalam pengelolaan human capital. Secara garis besar, identifikasi keempat informan penelitian ini disajikan pada Tabel 1.

\section{Strategi Pengelolaan Human Capital di Era New Normal}

Berdasarkan hasil wawancara secara mendalam, strategi pengelolaan human capital pada saat pandemi Covid-19 atau memasuki era new normal membuat perubahan sangat besar dan signifikan yang terjadi pada operasional pekerjaan di dalam perusahaan atau organisasi. Perubahan paling utama dalam masa new normal adalah terjadinya perubahan hari dan jam kerja, serta penerapan metode kerja work from home (WFH), seperti yang disampaikan oleh informan kesatu sebagai berikut:

"Jumlah order yang menurun dan kebijakan PSBB menyebabkan perusahaan melakukan sistem kerja rolling dan jam kerja dikurangi. Penerapan sistem kerja work from home untuk bagian sales dan admin. Penerapan sistem kerja outsourcing untuk bagian potong dan jahit. Sebelum pandemi, $60 \%$ order dioutsourcingkan, sekarang naik menjadi $90 \%$. Konsep new normal ini merupakan pendekatan kerja modern yang memaksimalkan penggunaan internet dan teknologi pendukung lainnya. Kebetulan di perusahaan kami karyawan bagian sales dan admin merupakan karyawan generasi milenial. Jumlah order yang menurun dan perubahan sitem kerja dengan konsep rolling mengharuskan perusahaan lebih memaksimalkan pengerjaan order dengan sistem outsourcing, lebih efektif waktu, dan biaya, serta tanggung jawab" (Manajer HRD perusahaan garmen; Informan 1).

Perusahaan manufaktur dengan produk garmen ini berdiri sejak tahun 1983. Perusahaan ini memproduksi pakaian yang made to order atau disain sesuai pesanan pembeli. Saat pandemi Covid-19 terjadi, perusaahaan memiliki karyawan sebanyak 70 orang. Karyawan milenial di perusahaan garmen ini mencapai $70 \%$ dari total jumlah karyawan. Berdasarkan data yang diperoleh melalui wawancara dan observasi secara langsung, beberapa kebijakan telah dilakukan perusahaan untuk mengadaptasi kondisi new normal di antaranya:

1. Menata kembali fungsi-fungsi pekerjaan yang dapat dilakukan secara WFH, khususnya yang sesuai dengan pola kerja generasi milenial dan beberapa fungsi dialihkan ke pihak ketiga (outsourcing).

2. Menciptakan budaya kerja work life balance dan tempat kerja yang open space.

3. Mengurangi jam kerja dan menerapkan sistem kerja rolling agar seluruh pekerja mendapatkan hari kerja secara adil.

4. Memangkas jumlah karyawan bagian potong dan jahit, serta mengalokasikan beberapa pekerjaan ke pekerja lepas atau outsourcing. Hal tersebut dilakukan agar pekerjaan memotong dan menjahit tidak dilakukan di gedung perusahaan, karena kondisi tersebut akan bertolak belakang dengan penerapan protokol Covid-19 di era new normal dengan mengabaikan social distancing.

5. Menetapkan metode work from home (WFH) untuk karyawan sales dan administrasi.

Lain halnya yang disampaikan oleh informan kedua yang berasal dari perusahaan akomodasi penginapan di sektor pariwisata yang menjadi bidang usaha paling terdampak pandemi Covid-19. Dalam menghadapi pandemi ini, sektor usaha pariwisata harus benar-benar memperhatikan biaya operasional agar perusahaan tidak mengalami ke- 
bangkrutan. Hal itu akibat dari sepinya tamu yang berkunjung ke Bali sejak pandemi Covid-19 dan diperparah dengan kebijakan pengetatan kegiatan wisatawan yang berkunjung ke Bali. Infoman kedua adalah seorang Manajer Accounting dan HRD di salah satu vila di kawasan Legian, Kuta, Bali yang memiliki jumlah karyawan sebanyak 27 orang. Secara keseluruhan, Vila ini memiliki dan mengoperasikan 25 kamar penginapan dengan rincian 16 kamar hotel dan 3 private villa yang masing-masing memiliki tiga kamar tidur. Informasi yang diberikan oleh informan kedua selaku Manajer HRD vila tersebut mengatakan:

"Ya... pada awalnya vila ini tutup tiga bulan di bulan Juni, Juli, dan Agustus 2020. Semua karyawan dirumahkan, yang masuk hanya karyawan dan sekedar bersih-bersih dan menjaga vila. Sebelum pandemi, jadwal kerja karyawan per shift ada 10 orang, lalu setelah vila ini mulai coba dibuka pada bulan September, sistem kerja karyawan menjadi tiga orang per shift dan dirolling agar semua mendapatkan giliran. Namun, jika ada tamu, maka karyawan yang libur siap dipanggil kerja secara mendadak apabila diperlukan. Dikarenakan saat ini per shift hanya berjumlah tiga orang yang kerja, jadi untuk pagi tiga orang, sore tiga orang, dan malam tiga orang, maka dari itu setiap karyawan yang masuk, apa pun bagian atau departemennya, maka ia harus bisa menguasai kerjaan semua divisi. Sebagai contoh pada saat security yang masuk, maka ia harus dapat menghandle check in tamu juga, yaitu bisa menyiapkan kamar, dan juga harus mampu menjaga area sesuai tugasnya. Yang lain juga begitu, misalnya yang kerja adalah bagian housekeeping, maka selain tugas utamanya menyiapkan kamar, dia juga harus mampu menghandle tamu, dan menjaga area layanan. Jadi, seluruh karyawan mulai diajarkan multitasking" (Manajer Accounting dan HRD perusahaan penginapan atau vila; Informan 2).

Berdasarkan pernyataan informan kedua dan observasi di lapangan, strategi vila tersebut dalam mengelola human capital di era new normal menggunakan pendekatan:

1. Pada masa awal pandemi, manajemen menutup penuh layanan akomodasi vila tersebut, karena dampak pandemi benar-benar membuat Bali lumpuh, sehingga manajemen hanya menugaskan security untuk berjaga di area vila.

2. Pada saat dibuka kembali dengan menerapkan protokol Covid-19, perusahaan melakukan improvisasi dengan menekan jumlah karyawan yang bekerja, yaitu hanya mempekerjakan enam orang per hari dengan dua orang per shift. Hal itu dilakukan dengan memfungsikan mereka untuk menjaga dan merawat property vila pada saat tidak ada tamu.

3. Perusahaan menerapkan sistem fleksibilitas, yaitu ketika ada tamu berkunjung, maka karyawan siap dipanggil sewaktu-waktu untuk bekerja, meskipun hal itu dilakukan secara mendadak.

4. Perusahaan menerapkan metode kerja WFH (work from home) untuk karyawan bagian sales dan e-commerce.

5. Perusahaan mengubah jam dan hari kerja bagian accounting, yaitu mereka masuk saat diperlukan saja.

6. Perusahaan merumahkan manajer vila untuk menekan biaya dan koordinasi, serta kepimpinanan diambil alih langsung oleh owner usaha.

7. Perusahaan menutup restaurant, karena adanya ketidakpastian pelanggan yang berkunjung untuk menghindari biaya ekstra pembelian bahan baku makanan dan mengurangi potensi kerusakan atau kedaluwarsa bahan mentah. 
8. Perusahaan memaksimalkan potensi karyawan, karena hampir seluruh karyawan merupakan pekerja milenial dengan mewajibkan mereka untuk menguasai semua jenis pekerjaan di semua departemen di dalam vila tersebut, yaitu Departemen Front Office, Security, Housekeeping, dan Kasir. Oleh karena itu, karyawan dituntut memiliki multitasking dalam bekerja.

Informan ketiga adalah Manajer Accounting dan HRD pada perusahaan kargo yang memberikan keterangan mengenai strategi perusahaannya dalam mengelola human capital di era new normal ini. Pendapat informan ketiga tersebut menyebutkan:

"Konsep ini merupakan pendekatan kerja modern yang memaksimalkan penggunaan internet dan teknologi pendukung lainnya. Kebetulan di perusahaan kami, karyawan bagian CS dan dokumen merupakan karyawan generasi milenial. Saat ini, perusahaan menerapkan aturan kerja dari rumah. Jumlah order yang menurun mengharuskan perusahaan melakukan perubahan sistem kerja dengan konsep rolling, sehingga pengeluaran perusahaan bisa ditekan. Menata kembali fungsi-fungsi pekerjaan yang bisa dilakukan secara WFH yang sangat cocok dengan generasi milenial atau bahkan dialihkan atau outsourcing ke pihak ketiga dan melakukan pelatihan online untuk pengembangan kemampuan karyawan generasi non-milenial" (Manajer Accounting dan HRD perusahaan kargo; Informan 3).

Berdasarkan infomasi yang disampaikan oleh informan ketiga, strategi yang dilakukan oleh perusahaan kargo dengan jumlah karyawan yang sebagian adalah kaum milenial, yaitu mengubah orientasi lebih ke bagian back office daripada bagian gudang. Upaya yang dilakukan perusahaan kargo tersebut adalah:

1. Menerapkan WFH kepada karyawan bagian Dokumen dan Customer Service (CS), karena karyawan pada bagian tersebut adalah karyawan milenial yang terbiasa menggunakan teknologi informasi. Di dalam operasionalnya, kedua departemen tersebut lebih intensif menggunakan teknologi infomasi pada saat pandemi, seperti bagian CS yang berkomunikasi melalui email dan whatsapp, serta bagian dokumen yang menerapkan prosedur pengajuan dokumen pengiriman secara online ke Kantor Bea Cukai dan Dinas Perhubungan, maupun kantor yang terkait lainnya.

2. Menerapkan konsep rolling karena berkurangnya volume pekerjaan akibat ditutupnya sejumlah penerbangan internasional menjadikan distribusi barang dari dan ke luar negeri banyak terhenti. Bahkan, beberapa negara belum membuka bordernya untuk penerbangan internasional. Hal ini berdampak pada volume pekerjaan yang menurun drastis, bahkan ada kalanya tidak ada sama sekali. Untuk itu, karyawan dapat diliburkan sewaktu-waktu.

3. Menerapkan kebijakan pembayaran gaji harian dengan sistem tidak bekerja tidak digaji (not come not pay) untuk menekan biaya gaji perusahaan sebagai dampak penerapan sistem rolling dan meliburkan sejumlah karyawan pada saat tidak ada volume pekerjaan pengiriman atau pengambilan barang.

4. Melakukan pengembangan sistem online untuk pengembangan keahlian karyawan, misalnya pelatihan online yang diadakan oleh dinas terkait dan pengembangan sistem aplikasi untuk memudahkan pemasaran online dan operasional kantor.

Selanjutnya, informan keempat adalah Kepala HRD salah satu kampus sekolah tinggi di Bali. Hasil wawancara dari beberapa informan sebelumnya menyatakan bahwa dampak pandemi Covid-19 sangat signifikan terhadap turunnya pemasukan bagi organisasi, volume pekerjaan semakin sedikit, bahkan ada pula yang sampai pada keputusan 
pentutupan sementara usahanya. Hasil yang berbeda disampaikan oleh informan dari sektor pendidikan. Operasional sektor pendidikan tetap dapat berjalan, tetapi aplikasi teknisnya berbeda. Penurunan volume pekerjaan atau pun penurunan drastis pemasukan tidak dirasakan, karena sektor pendidikan lebih berfokus kepada teknis operasional seperti apa yang dikatakan informan keempat sebagai berikut:

"Tentu ada perbedaan sistem kerja pada era new normal saat ini dengan sebelum terjadinya pandemi. Jadi, kami berusaha membentuk budaya baru bagaimana agar tetap bisa bekerja di tengah pandemi tentunya dengan tetap produktif tanpa menimbulkan risiko kesehatan bagi kita semua. Kami sudah menerapkan berbagai cara seperti melakukan full-WFH, kemudian diganti dengan sistem kerja 25\% setiap harinya. Jadi, kami bekerja secara bergantian, tentunya ada pembagian kerja juga yang dilakukan untuk setiap ruangan kantor. Penerapan prokes yang ketat sebelum masuk kantor. Dan juga adanya perubahan shift yang dulunya sebelum pandemi ada dua shift yaitu pagi dan sore, tapi sekarang hanya satu shift pagi saja. Pada saat new normal ini, kami belajar untuk melakukan segala sesuatunya serba online, baik itu meeting dan kegiatan perkuliahan. Pada saat WFH, kita menerapkan beberapa aturan seperti wajib fast response, bisa dihubungi kapan pun. Kampus juga memberikan fasilitas kuota, jadi tidak ada alasan untuk tidak fast response karena kendala kuota. Kemudian, kampus juga mengharuskan setiap karyawan untuk mengumpulkan laporan setiap harinya dengan tujuan untuk bisa mengetahui sejauh mana progress yang dicapai karyawan dalam menyelesaikan pekerjaannya. Dengan begitu, karyawan bisa produktif karena adanya sistem laporan yang harus dikumpulkan setiap harinya maksimal dua jam setelah jam bekerja berakhir" (Kepala HRD kampus sekolah tinggi; Informan 4).

Hasil wawancara dengan informan keempat tersebut menunjukkan bahwa kampus menitikberatkan produktivitas karyawannya. Untuk itu, kampus sekolah tinggi ini menerapkan beberapa strategi dalam pengelolaan human capital di lingkungan kampus, yaitu:

1. Menerapkan WFH pada sebagian karyawan, baik secara full-WFH atau hanya $75 \%$ WFH, serta menerapkan protokol kesehatan yang ketat saat memasuki kantor.

2. Memberlakukan satu shift kerja. Hal tersebut dikarenakan hanya $25 \%$ karyawan yang masuk kantor, sehingga kebijakan tersebut tidak dapat mengcover dua shift kerja seperti yang diberlakukan sebelum pandemi.

3. Memberikan kuota internet kepada karyawan agar mereka mampu memaksimalkan kinerja dan menjaga keberlangsungan aktivitas layanan kampus seperti biasa.

4. Menerapkan kewajiban mengumpulkan laporan harian untuk mengontrol kinerja setiap karyawan dan mengukur produktivitas kerjanya.

Berdasarkan informasi dari informan, generasi milenial merupakan generasi yang memiliki potensi besar, memiliki karakter unik, berpikiran out of the box, lebih kreatif, sangat ahli dalam penguasaan teknologi informasi, lebih suka cara yang lebih sederhana dan praktis, memiliki daya tangkap yang kuat, lebih beorientasi pada pencapaian hasil dengan cara yang mereka inginkan, tidak suka cara kuno atau terlalu terstruktur, dan memiliki semangat kuat dalam bekerja. Hal tersebut sejalan dengan penelitian Fudin (2019) yang memaparkan bahwa generasi milenial merupakan orang yang memiliki bakat luar biasa, karena mereka berkembang dalam dunia teknologi yang sudah pesat. Oleh karena itu, mereka lebih mudah menyesuaikan diri dengan pekerjaan yang mereka lakukan. Untuk mengasah kemampuan generasi milenial, maka organisasi perlu meli- 
batkan mereka dalam pelatihan untuk menanamkan rasa tanggung jawab yang tinggi. Proses pengembangan rasa tanggung jawab bagi generasi milenial dapat dilakukan dengan memberikan kepercayaan kepada mereka untuk memegang suatu posisi atau pekerjaan yang menuntut kemampuan mereka untuk memberikan hasil maksimal pada kedudukan yang mereka tempati atau pekerjaan yang mereka lakukan. Namun, penelitian ini juga menemukan bahwa generasi milenial justru lebih memiliki emosi yang cepat berubah dan tidak stabil, cenderung mudah terlibat dalam situasi konflik, dan memiliki kecerdasan emosi yang tidak terkontrol. Dengan demikian, kecerdasan emosi menjadi faktor terpenting dalam membangun sumber daya yang kompetitif secara global pada era new normal (Indrawati, 2020).

Dari beberapa hal yang telah dipaparkan tersebut, maka temuan penting dalam penelitian ini dan belum ada pada penelitian sebelumnya adalah pengelolaan human capital pada suatu organisasi atau unit usaha di era new normal ini perlu memperhatikan kebutuhan sosial generasi milenial. Bagaimana pun juga, generasi milenial memiliki potensi untuk meningkatkan keuntungan bagi organisasi. Oleh karena itu, manajemen perlu mengikuti arus gaya hidup dan gaya kerja generasi milenial dalam pengelolaan human capital pada dirinya. Dalam strategi pengelolaan human capital, penelitian Ong dan Mahazan (2020) menyatakan bahwa generasi milenial lebih mahir menggunakan teknologi informasi, tetapi mereka kurang sabar berada dalam organisasi yang penuh dengan tata aturan dan prosedurnya. Hal ini tidak sepenuhnya sejalan dalam penelitian ini, karena karyawan generasi milenial cukup mahir dalam penggunaan teknologi informasi, tetapi pandemi Covid-19 seakan memaksa dan melatih mereka untuk lebih sabar menerima perubahan yang terjadi. Salah satu perubahan yang menonjol tersebut adalah metode bekerja dari rumah (WFH) atau pun proses bekerja secara bergiliran, serta tantangan berkurangnya penghasilan mereka, karena kebijakan organisasi untuk merumahkan atau meliburkan karyawannya sementara waktu. Mereka menyadari bahwa kondisi ini merupakan sebuah keterpaksaan akibat sektor ekonomi yang terkontraksi, khususnya di Bali, sehingga kelumpuhan ekonomi terjadi akibat pandemi. Jadi, pilihan untuk berpindah perusahaan menjadi semakin kecil dan mereka lebih memilih untuk bersabar terhadap pekerjaannya saat ini.

\section{Faktor Pendukung dan Penghambat dalam Pengelolaan Human Capital}

Berdasarkan triangulasi sumber data yang digunakan, maka penelitian ini menemukan adanya beberapa faktor yang dapat mendukung kinerja karyawan milenial dalam strategi pengelolaan human capital organisasi, di antaranya:

1. Pola pikir dan karakter generasi milenial seringkali out of the box, penuh kreativitas, inovatif, dan cepat beradaptasi dengan teknologi baru. Oleh karena itu, jika suatu pekerjaan membutuhkan koordinasi dan penyelesaian yang cepat, maka hal itu dapat direalisasikan menggunakan program atau aplikasi yang ada di dalam smartphone karyawan, seperti Email, Whatsapp, Zoom, Microsoft office for mobile, dan Camscanner.

2. Karyawan milenial mudah beradaptasi dengan metode bekerja dari rumah (WFH). Metode tersebut dilakukan, karena karyawan milenial lebih memprioritaskan produktivitas kerja atau hasil yang dicapai daripada harus bekerja dengan jam kerja yang monoton. 
3. Karyawan milenial mudah mempelajari suatu hal baru untuk membantu departemen lain atau penguasaan multitasking. Hal itu dikarenakan karyawan milenial masih memiliki semangat yang tinggi dan giat bekerja.

4. Karyawan milenial memiliki mindset yang dapat diubah atau diarahkan. Mindset tersebut berguna untuk memotivasi para pekerja milenial untuk lebih menerima perubahan dan memberikan kesadaran pentingnya hasil kerja meskipun lokasinya berbeda. Selain itu, mindset juga berguna untuk mengurangi sindrom kerja di kantor dan mengatasi stres atas perubahan-perubahan yang dialami.

Selain faktor-faktor yang mendukung, perusahaan maupun organisasi juga perlu mencermati beberapa faktor penghambat dalam proses pengelolaan human capital pada karyawan milenial. Pandemi Covid-19 yang mempengaruhi seluruh aspek usaha di Indonesia juga menjadi faktor penghambat utama bagi berkembangnya organisasi bisnis. Namun, faktor penghambat spesifik terjadi pada bidang usaha yang berbedabeda. Hasil penelitian ini mengungkapkan beberapa faktor spesifik yang menghambat pengelolaan human capital, di antaranya:

1. Menurunnya volume pekerjaan dikarenakan turunnya pembelian/pesanan/kunjungan tamu yang mengakibatkan turunnya pendapatan perusahaan. Hal itu terjadi karena adanya kebijakan pemerintah membatasi kegiatan masyarakat.

2. Jika kantor/vila/kampus membutuhkan karyawan untuk masuk kerja, tetapi karyawan tidak siap untuk datang ke tempat kerja pada saat yang mendadak tersebut, maka hal itu akan menjadi hambatan untuk bekerja.

3. Karyawan milenial merasa terganggu dengan aktivitas di rumah yang menjadikan sulit untuk berkonsentrasi jika ada gangguan karena kepentingan keluarga.

4. Karyawan milenial cenderung suka memilih pekerjaan. Pada umumnya, pekerjaan yang disukai akan lebih baik hasilnya dibandingkan hasil pekerjaan di bagian atau departemen lainnya yang kurang disukai. Hal ini akan mengakibatkan penurunan kinerja pada departemen yang tidak disukai.

5. WFH membuat karyawan kadang memberikan respon cukup lama, karena antara bekerja untuk organisasi dan kegiatan rumah tangga terjadi campur aduk.

6. Karyawan milenial cenderung memiliki kondisi emosional yang labil dan rentan memicu terjadinya konflik ketika mereka menyelesaikan pekerjaan.

7. Penutupan rute penerbangan internasional mengakibatkan aktivitas pekerjaan yang berhubungan dengan negara lain menjadi terhenti, seperti tidak adanya tamu yang menginap, berbelanja, melakukan kegiatan bisnis lainnya, dan menutup aktivitas pengiriman barang ke luar negeri.

8. Koneksi internet yang tidak stabil mengakibatkan melambatnya atau bahkan terputusnya komunikasi untuk mengkoordinasikan pekerjaan antarkaryawan yang bekerja di rumah (WFH).

\section{KESIMPULAN DAN SARAN}

Secara keseluruhan, strategi pengelolaan human capital pada karyawan milenial di era new normal yang lebih dominan adalah upaya mengatasi perubahan prosedur serta hari dan jam kerja. Kebijakan pemerintah berupa Pembatasan Sosial Berskala Besar (PSBB) atau Pembatasan Kegiatan Masyarakat (PKM) mengharuskan pembatasan jumlah karyawan yang masuk bekerja di tempat kerja, sedangkan sisanya bekerja dari rumah (WFH). Akibat kebijakan ini, dua sisi yang terdampak adalah operasional per- 
usahaan dan karyawan milenial yang bekerja. Dari sisi perusahan, pandemi Covid-19 berdampak terjadap menurunnya penghasilan yang diperoleh perusahaan dan berkurangnya aktivitas operasionalnya. Sesuai aturan pemerintah, perubahan dengan cara membagi jadwal kerja dan jam kerja karyawan, membagi sistem rolling, menggunakan metode WFH, dan memaksimalkan skill karyawan menjadi multitasking dipandang perlu untuk dilakukan. Dari sisi karyawan, pandemi Covid-19 berdampak pada penghasilan karyawan, yaitu karyawan menerima gaji dengan nilai yang jauh berkurang dari sebelum pandemi. Bahkan, karyawan harus siap menerima kebijakan pemutusan hubungan kerja (PHK) sewaktu-waktu demi menekan biaya operasional organisasi.

Implikasi teoritis penelitian ini adalah upaya untuk mengukur strategi pengelolaan human capital di era new normal melalui pemanfaatan teknologi infomasi yang lebih dikuasai oleh generasi milenial, sehingga upaya tersebut dapat mempertahankan eksistensi dan operasional usaha agar tetap berjalan lancar untuk mencapai tujuan organisasi. Selanjutnya, implikasi manajerial dari penelitian ini adalah hasil penelitian dapat digunakan oleh perusahaan yang menerapkan protokol Covid-19 dalam menjalankan usahanya saat ini. Dalam era new normal, banyak batasan-batasan kegiatan masyarakat dilakukan, sehingga aktivitas perusahaan menurun. Di sisi lain, perusahan juga dituntut untuk tetap melakukan operasi usaha dan mencapai tujuan organisasi. Dengan demikian, faktor-faktor yang perlu dimaksimalkan pada era new normal ini, di antaranya adalah: (1) Menerapkan dan mengarahkan manajemen waktu kepada karyawan yang bekerja dari rumah (WFH) agar mereka dapat membagi waktunya antara pekerjaan kantor dan perannya di dalam keluarga. Jika keduanya dapat dilakukan dengan baik dan benar, maka operasional perusahaan tidak mengalami hambatan; (2) Mengubah gaya kepemimpinan di suatu perusahaan mengikuti trend atau style generasi milenial dengan memfokuskan orientasi kepada hasil yang dicapai dan mengutamakan cara kerja yang praktis dan simpel, serta mengetahui batasan jam kerja agar tidak mengganggu atau membebani karyawan pada saat bekerja dari rumah; dan (3) Melaksanakan webinar atau pelatihan guna meningkatkan keahlian karyawan dan memberikan konseling bagi manajemen untuk mengelola stres, serta memberikan pengayoman rehabilitasi psikologis untuk menekan stres karyawan yang bekerja dari rumah.

Secara umum, penelitian ini masih memiliki beberapa kelemahan dan kendala, sehingga penelitian lebih lanjut di masa mendatang disarankan untuk memperhatikan hal-hal seperti: (1) Keberagaman latar belakang informan, baik dari segi usia, lokasi tempat tinggal, dan tingkat pendidikan yang memungkinkan keberagaman persepsi dan hasil dalam memberikan jawaban, sehingga penelitian mendatang sebaiknya memperbanyak jumlah informan dan cakupan usia, lokasi, dan latar belakang pendidikan informan; (2) Penelitian ini hanya dilakukan di Kabupaten Badung sebagai daerah yang paling terdampak oleh Pandemi Covid-19, sehingga penelitian lebih lanjut diharapkan tidak hanya terbatas pada satu lokasi atau area saja, sehingga penambahan cakupan area lain perlu dipertimbangkan; dan (3) Penelitian selanjutnya diharapkan dapat menambah jenis atau sektor usaha pada bidang-bidang lainnya yang tidak terbatas hanya pada empat bidang usaha yang ada di dalam penelitian ini.

\section{DAFTAR REFERENSI}

Abbas, W. A. F. (2019). Strategi Pengembangan SDM dalam Persaingan Bisnis Industri Kreatif di Era Digital. Adliya: Jurnal Hukum dan Kemanusiaan, 13(1), 115-126. 
Ali, H., \& Purwandi, L. (2017). The Urban Middle-Class Indonesia: Financial and Online Behavior. Jakarta: PT Alvara Strategi Indonesia. Diakses tanggal 10 Januari 2021 di https://alvara-strategic.com/wp-content/uploads/whitepaper/TheUrban-Middle-Class-Millenials.pdf.

Amstrong, M., \& Taylor, S. (2014). Armstrong's Handbook of Human Resource Management Practice. 13th Editions. London: Kogan Page, Ltd. https://doi.org/10.4135/9780857021496.

Bramasta, D. B. (2020). Mengenal Apa Itu New Normal di Tengah Pandemi Corona. Kompas.com, 20 Mei 2020. Diakses tanggal 10 Januari 2021 di https://www.kompas.com/tren/read/2020/05/20/063100865/mengenal-apa-itunew-normal-di-tengah-pandemi-corona-?page $=$ all.

Burud, S., \& Tumolo, M. (2004). Leveraging the New Human Capital: Adaptive Strategies, Results Achieved, and Stories of Transformation. UNKNO

Ciriello, V. M., Dempsey, P. G., Maikala, R. V, \& O’Brien, N. V. (2008). Secular changes in psychophysically determined maximum acceptable weights and forces over 20 years for male industrial workers. Ergonomics, 51(5), 593-601. https://doi.org/10.1080/00140130701733590.

David, F. R., \& David, F. R. (2017). Strategic Management: Concepts and Cases, A Competitive Advantage Approach. 16th Edition. Boston: Pearson.

Fahmi, I. (2013). Manajemen Strategis Teori dan Aplikasi. Bandung: Alfabeta.

Faiza, A., \& Firda, S. J. (2018). Arus Metamorfosa Milenial. Kendal: Penerbit Ernest.

Fareed, M., Noor, W. S. W. M., Isa, M. F. M., \& Salleh, S. S. M. M. (2016). Developing human capital for Sustainable Competitive Advantage: The Roles of Organizational Culture and High-Performance Work System. International Journal of Economic Perspectives, 10(4), 655-673.

Febrianindya, F. (2018). Kantor Millennial-Friendly Bukan Sekedar Tampilan Fisik yang Warna Warni. Buletin PPM Manajemen. Diakses tanggal 10 Januari 2021 di https://dev.ppm-manajemen.ac.id/id_ID/blog/acara-manajemen-17/post/kantormillennial-friendly-1592.

Firnaliyanti, A. A., Mintarti, S., \& Asmapane, S. (2020). Pengaruh Intellectual Capital terhadap Pertumbuhan Laba dan Nilai Pasar Saham Perusahaan Properti dan Real Estate yang Terdaftar di Bursa Efek Indonesia. Jurnal Ilmu Akuntansi Mulawarman (JIAM), 4(3).

Fudin, A. (2019). Strategi Pengembangan Manajemen Sumber Daya Manusia bagi Generasi Millenial. Nidhomul Haq: Jurnal Manajemen Pendidikan Islam, 4(2), 169-185. https://doi.org/10.31538/ndh.v4i2.342.

Gallup (2016). State of The American Workplace: Employee Engagement Insights For US Business Leaders. USA: Gallup, Inc.

Hariadi, B. (2003). Strategi Manajemen: Strategi Memenangkan Perang Bisnis. Edisi 1. Malang: Banyumedia Publishing.

Hasibuan, M. (2016). Manajemen Sumber Daya Manusia. 12th Edition. Jakarta: Bumi Aksara.

Indrawati, F. (2020). Sumber Daya Manusia yang Kompetitif di Era Kenormalan Baru. Prosiding Seminar Nasional dan Diskusi Panel Pendidikan Matematika Universitas Indraprasta PGRI Jakarta, 80, 145-150. 
Kasali, R. (2017). Disruption "Tak ada yang tak bisa diubah sebelum dihadapi, motivasi saja tidak cukup". Jakarta: PT Gramedia Pustaka Utama.

Kharisma, M., Prasilowati, S. L., \& Ayuningtyas, E. A. (2019). Pengaruh Budaya Organisasi dan Kepuasan Kerja terhadap Kinerja Karyawan dengan Komitmen Organisasi sebagai Variabel Intervening. Jurnal Pengembangan Wiraswasta, 21(2), 135-150.

Kementerian Kesehatan Republik Indonesia (2020). Keputusan Menteri Kesehatan Republik Indonesia Nomor HK.01.07/MenKes/413/2020 Tentang Pedoman Pencegahan dan Pengendalian Corona Virus Disease 2019 (Covid-19). Diakses tanggal 10 Januari $2021 \mathrm{di}$ https://infeksiemerging.kemkes.go.id/download/KMK_No._HK.01.07-MENKES413-2020_ttg_Pedoman_Pencegahan_dan_Pengendalian_COVID-19.pdf.

Kementerian Keuangan Republik Indonesia (2021). Pajak Penjualan Atas Barang Mewah Atas Penyerahan Barang Kena Pajak Yang Tergolong Mewah Berupa Kendaraan Bermotor Tertentu Yang Ditanggung Pemerintah Tahun Anggaran 2021. In Kementrian Keuangan Republik Indonesia. https://jdih.kemenkeu.go.id/download/1b38b55f-3ad6-49cd-950b0d3c9b21a410/20 PMK.010 2021Per.pdf.

Kementerian Pemberdayaan Perempuan dan Perlindungan Anak (2018). Statistik Gender Tematik: Profil Generasi Milenial Indonesia. Diakses tanggal 10 Januari 2021 di https://www.kemenpppa.go.id/lib/uploads/list/9acde-buku-profilgenerasi-milenia.pdf.

Kumparan (2017). Milenial Memilih Bekerja di Startup, Apa Alasannya? Diakses tanggal 10 Januari 2021 di https://kumparan.com/millennial/milenial-memilihbekerja-di-startup-apa-alasannya-21dM5TYPuJ/.

LonivHR (2017). Pentingnya Manajemen SDM untuk Karyawan Generasi Milenial. Diakses tanggal 10 Januari $2021 \mathrm{di}$ https://www.linovhr.com/manajemen-sumberdaya-manusia-generasi-milenial/.

Miles, M. B., \& Huberman, A. M. (1994). Qualitative Data Analysis: An Expanded Sourcebook. Thousands Oaks, California: SAGE Publications, Inc.

Musthofa, M. (2020). PLN Organizational Leaders Manajemen Talent sebagai Strategi Pengelolaan Human Capital: Studi Kasus Manajemen Talent sebagai Strategi Pengelolaan Human Capital PT PLN (Persero). Kilat, 9(1), 74-84. https://doi.org/10.33322/kilat.v9i1.786.

Nurkholis, A. (2018). Teori Pembangunan Sumberdaya Manusia: Human Capital Theory, Human Investment Theory, Human Development Theory, Sustainable Development Theory, People-Centered Development Theory. Center for Open Science., 8(7), 1-16.

Ong, J. O., \& Mahazan, M. (2020). Strategi Pengelolaan SDM dalam Peningkatan Kinerja Perusahaan Berkelanjutan di Era Industri 4.0. Business Economic, Communication, and Social Sciences (BECOSS) Journal, 2(1), 159-168. https://doi.org/10.21512/becossjournal.v2i1.6252.

Otoritas Jasa Keuangan (2020). Peraturan OJK Nomor 48/POJK.03/2020. Diakses tanggal 10 Januari 2021 di https://www.ojk.go.id/id/regulasi/Documents/Pages/ Perubahan-Atas-Peraturan-Otoritas-Jasa-Keuangan-Nomor-11-tentang-StimulusPerekonomian-Nasional/pojk 48-2020.pdf. 
Priyana, I. (2016). Kajian Pemberdayaan Sumber Daya Manusia dalam Upaya Mengoptimalkan Potensi Human Capital Perusahaan (Studi Kasus pada PT SIMNU Bandung). Tesis, Universitas Pasundan.

Rastogi, P. N. (2002). Knowledge Management and Intellectual Capital as a Paradigm of Value Creation. Human Systems Management, 21, 229-240.

Rosidi, A. (2020). Penerapan New Normal (Kenormalan Baru) dalam Penanganan Covid-19 sebagai Pandemi dalam Hukum Positif. Jurnal Ilmiah Rinjani, 8(2), 193-197.

Salehudin, I. (2010). Invest in Yourself: Aplikasi Konsep Human Capital dari Sudut Pandang Karyawan. Manajemen Usahawan Indonesia, 06(XXXIX), 1-11.

Sangkala, S. (2006). Intellectual Capital Management: Strategi Baru Membangun Daya Saing Perusahaan. Jakarta: Yapensi.

Satya, V. E. (2018). Strategi Indonesia Menghadapi Industri 4.0. Info Singkat, Pusat Penelitian Badan Keahlian DPR RI, 10(9), 19-24.

Smola, K. W., \& Sutton, C. D. (2002). Generational differences: Revisiting Generational Work Values for The New Millennium. Journal of Organizational Behavior, 23, 363-382. https://doi.org/10.1002/job.147.

Sugiyono, S. (2018). Metode Penelitian Kuantitatif, Kualitatif, dan R\&D. Bandung: Alfabeta.

Tampubolon, M. P. (2020). Change Management: Manajemen Perubahan, Individu, Tim Kerja, Organisasi. Bogor: Mitra Wancana Media.

Taufiqurokhman, T. (2016). Manajemen Strategik. Jakarta: Fakultas Ilmu Sosial dan Ilmu Politik Universitas Prof. Dr. Moestopo Beragama.

Triangga, P., Mubyl, M., \& Abdullah, A. (2020). Perumusan Strategi Pemasaran pada Objek Wisata Puncak Pasapa' di Desa Saludengen Kecamatan Bambang Kabupaten Mamasa. AkMen Jurnal Ilmiah, 17(1), 66-76.

Twenge, J. M., Campbell, S. M., Hoffman, B. J., \& Lance, C. E. (2010). Generational Differences in Work Values: Leisure and Extrinsic Values Increasing, Social and Intrinsic Values Decreasing. Journal of Management, 36(5), 1117-1142. https://doi.org/10.1177/0149206309352246.

Wheelen, T. L., \& Hunger, J. D. (2010). Concepts in Strategic Management and Business Policy. New Jersey: Pearson Education.

Wiratmini, N. P. E. (2021). Badung Pecah Rekor Pertumbuhan Ekonomi Minus 16,52 Persen. Bisnis.com, 9 Maret. Diakses 7 Juni 2021 https://bali.bisnis.com/read/20210309/538/1365530/badung-pecah-rekorpertumbuhan-ekonomi-minus-1652-persen.

Yulita, S., Nugroho, S. P., \& Astuti, N. (2018). Analisis Lima Kekuatan Porter terhadap Keunggulan Bersaing pada PT Ajinomoto Sales Indonesia Kantor Cabang Bangka. Jurnal Progresif Manajemen Bisnis, 23(2), 43-49.

Yunus, E. (2016). Manajemen Strategis. Yogyakarta: Andi Offset. 